\title{
Analisis Penerapan Theory of Consumer Acceptance Technology Terhadap Layanan Si Demang Pada Aplikasi Hallo Palembang Di Kelurahan Kalidoni
}

\author{
Anggun Pratiwi ${ }^{1}$, Evi Fadilah ${ }^{2}$, Sri Rahayu ${ }^{3}$ \\ ${ }_{1}^{1}$ nformation System Departement, Raden Fatah Islamic State University, Palembang, Indonesia \\ Email: ${ }^{1}$ anggunpratiwi0813@gmail.com, ${ }^{2}$ evifadilah_uin@radenfatah.ac.id, \\ 3srirahayu@radenfatah.ac.id
}

\begin{abstract}
Si Demang merupakan sebuah menu pelayanan masyarakat secara online, berupa layanan administrasi yang terdapat di kelurahan dan kecamatan di kota Palembang. Kemunculan teknologi baru ini menimbulkan berbagai reaksi masyarakat dalam penggunaannya. Sejauh ini belum ada penelitian yang meneliti bagaimana penerimaan Si Demang oleh masyarakat terutama di kelurahan Kalidoni, sementara penggunaan nya mengalami penurunan. Oleh karena itu penelitian ini bertujuan untuk melihat penerimaan Si Demang di kelurahan Kalidoni dengan memprediksi faktor faktor yang mempengaruhi sikap penggguna terhadap minat menggunakan layanan Si Demang di Kelurahan Kalidoni menggunakan metode Consumer Acceptance Technology (CAT). Penelitian ini menggunakan semua variabel yang ada pada metode CAT. Data dikumpulkan menggunakan kuisioner yang disebarkan kepada 375 responden. Analisis data mengunakan analisis deskriptif, analisis structural equation modeling (SEM) dengan metode partial least squares (PLS). Hasil penelitian menunjukkan bahwa persepsi kegunaan, kesenangan, keinginan dan dominasi berpengaruh signifikan terhadap sikap menggunakan layanan Si Demang. Keunggulan relatif dan persepsi kemudahan tidak berpengaruh signifikan terhadap sikap dalam menggunakan layanan Si Demang. Jadi untuk meningkatkan penggunaan layanan Si Demang maka persepsi kegunaan, kesenangan, keinginan, dan dominasi perlu ditingkatkan.
\end{abstract}

Kata Kunci: Si Demang, Theory of Consumer Acceptance Technology (CAT), Structural Equation Modeling (SEM)

\section{PENDAHULUAN}

Si Demang merupakan layanan administrasi online dari pemerintah kepada masyarakat di kelurahan kota Palembang. Tujuan layanan Si Demang ialah untuk mempermudah masyarakat dalam pengurusan berkas administrasi dengan memangkas prosedur pelayanan administrasi, cukup di kelurahan saja. Penggurusan berkas administrasi 


\section{Journal of Software Engineering Ampera}

Vol. 2, No. 3, Oktober 2021 e-ISSN: 2775-2488

https://journal-computing.org/index.php/journal-sea/index

secara konvensional dinilai membutuhkan waktu lama dan memiliki prosedur panjang dalam pengurusan berkas, Dengan adanya pelayanan masyarakat secara online dapat mempercepat proses administrasi dengan memanggkas prosedur pelayanan secara konvensional serta meminimalis biaya yang dibutuhkan masyarakat dalam mengurus berkas administrasi.

Untuk evaluasi terhadap penggunaan layanan Si Demang telah diujicobakan kepada 34 kelurahan yang ada di Kota Palembang, salah satunya ialah di Kelurahan Kalidoni. Berdasarkan informasi yang diberikan administror layanan Si Demang di Dinas Komunikasi dan Informatika Kota Palembang mengalami penurunan hingga 20\%. Hal ini menunjukkan kurangnya minat masyarakat menggunakan layanan Si Demang. Dikarenakan layanan Si Demang merupakan salah satu kunci penting dalam upaya pemerintah kota Palembang untuk mewujudkan Palembang Smart City dan dalam upaya evaluasi kekurangan dari layanan Si Demang, maka Dinas Komunikasi dan Informasi Kota Palembang berupaya memaksimalkan bagaimana agar layanan Si Demang dapat digunakan secara maksimal oleh masyarakat. Oleh karena itu minat penggunaan layanan Si Demang perlu diperhatikan.

Salah satu teori yang menggukur penerimaan teknologi populer yang digunakan sejauh ini adalah teori TAM atau Technology Acceptance Model, kebanyakan teori teori yang populer mengukur penerimaan teknologi hanya berdasarkan unsur kognitifnya saja, tanpa mendeskripsikan dengan rinci unsur afektifnya. Menurut (Kulviwat et al., 2007)penerimaan seseorang terhadap teknologi tidak hanya diukur berdasarkan unsur kognitifnya saja, namun juga berdasarkan feel yang dirasakan pengguna pada saat menggunakan teknologi tersebut. Pengguna tertarik menggunakan teknologi tidak hanya untuk merasakan manfaat yang diberikan, namun juga untuk mendapatkan experience atau pengalaman dalam menggunakanya, karena dibeberapa waktu pengguna bisa saja menolak teknologi baru jika dirasa teknologi yang lama lebih memberikan self experience yangg baik.

Berdasarkan hal tersebut untuk memenuhi ketidakcukupan pemahaman mengenai penerimaan teknologi (Kulviwat et al., 2007)membentuk sebuah theory of consumer acceptance technology yang menghubungkan aspek kognitif dan afektif. Unsur kognitif diambil dari metode TAM yaitu perceive usefullness atau persepsi kegunaan dan perceive ease of use atau persepsi kegunaan. Unsur afektif diambil dari metode PAD yaitu pleasure atau kesenangan, arrousal atau keinginan, dan dominance atau dominansi.

Sejauh ini belum ada penelitian yang meneliti bagaimana penerimaan Si Demang ditengah masyarakat. Untuk memaksimalkan evaluasi terhadap minat penggunaan layanan Si Demang, Maka penelitian ini dilakukan untuk melihat penerimaan layanan Si Demang dengan menganalisis faktor faktor yang mempengaruhi sikap seseorang terhadap minat menggunakan layanan Si Demang. Dengan menggunakan theory of 


\section{Journal of Software Engineering Ampera}

Vol. 2, No. 3, Oktober 2021 e-ISSN: 2775-2488

https://journal-computing.org/index.php/journal-sea/index

consumer acceptance technology dapat mengetahui penerimaan pengguna terhadap layanan Si Demang dengan mencakup kedua unsur logika kognitif dan emosi pengguna atau affect selama penggunaan. Dan diharapkan dari penelitian ini dapat memberikan wawasan serta saran yang membangun guna meningkatkan performa dan penggunaan Si Demang oleh masyarakat di masa yang akan datang.

\section{KERANGKA PEMIKIRAN TEORITIS DAN PERUMUSAN HIPOTESIS}

\subsection{Pleasure Arrousal Dominance (PAD)}

Pleasure Arousal Dominance atau PAD merupakan teori yang dikembangkan oleh (Mehrabian \& Russell, 1974) yang menegaskan bahwa semua respon emosional seseorang terhadap fisik ataupun lingkungan sosial dapat ditangkap dengan 3 dimensi pengaruh yaitu, pleasure atau kesenangan, arousal atau keinginan, dan dominance atau dominansi. Ketiga dimensi ini mewakili perasaan seseorang yang pada gilirannya dapat mempengaruhi perilaku mendekat atau menghindari teknologi.

\subsection{Technology Acceptance Model (TAM)}

Technology acceptance model atau TAM merupakan teori yang dikembangkan pertama kali oleh Fred Davis pada tahun 1989. TAM merupakan adaptasi dari theory of reasoned action (TRA) untuk pemodelan penerimaan pengguna terhadap teknologi informasi dan untuk memahami sikap pengguna terhadap teknologi yang digunakan.

\subsection{Theory of Consumer Acceptance Technology (CAT)}

Theory of consumer acceptance technology dikembangkan oleh (Kulviwat et al., 2007) merupakan teori yang menghubungkan aspek kognitif atau nalar dan aspek afektif atau pengaruh. Dilatar belakangi oleh banyaknya penelitian yang memprediksi faktor penerimaan teknologi yang hanya memprediksi kognisi dan jarang memasukkan unsur affect atau afektif. Teori CAT meningkatkan prediksi minat adopsi produk berteknologi tinggi dengan mengintegrasikan TAM (technologi acceptance model) dan PAD (pleasure arousal dominance) serta membangun kognitif tambahan ke model TAM.

Sistem Informasi Administrasi Online Masyarakat Kota Palembang (Si Demang) Layanan Si Demang merupakan salah satu layanan yang terdapat pada website maupun aplikasi Hallo Palembang. Si Demang pertama kali dipublikasikan pada 17 November 2018 oleh Dinas Komunikasi dan Informatika Kota Palembang. Beberapa menu layanan yang terdapat dalam layanan Si Demang yaitu surat izin usaha perdagangan, surat izin pemakaman dan pengabuan, surat tanda daftar perusahaan, surat izin penyelenggaraan reklame insidentil, surat izin operasional izin kecantikan dan pangkas rambut dan beberapa layanan administrasi lainnya. Dalam hal penggunaan Si Demang 


\section{Journal of Software Engineering Ampera}

Vol. 2, No. 3, Oktober 2021 e-ISSN: 2775-2488

https://journal-computing.org/index.php/journal-sea/index

dapat diakses secara umum oleh masyarakat dengan medownload kemudian mengakses aplikasi Hallo Palembang ataupun melalui website resmi https://hallo.palembang.go.id/LayananOnline. Si Demang memberikan kemudahan dengan mempercepat proses administrasi di kelurahan dengan cara memangkas prosedur pelayanan secara konvensional serta meminimalis biaya yang dibutuhkan masyarakat dalam mengurus berkas administrasi.

\subsection{Pengaruh Keunggulan Relatif Terhadap Persepsi Kegunaan dan Sikap}

Membandingkan keunggulan relatif dan kegunaan, keunggulan relative difokuskan pada sejauh mana inovasi teknologi dianggap lebih baik dari pendahulunya, sedangkan kegunaan yang dirasakan mencerminkan keyakinan bahwa teknologi membantu melakukan suatu fungsi tertentu. Seseorang memilih mengadopsi suatu teknologi karena memiliki keunggulan dari teknologi lain atau lebih unggul dari teknologi sebelumnya. Teknologi diciptakan tentunya memiliki value kegunaan dan keunggulan yang dapat berpengaruh terhadap penerimaan dan penggunaan teknologi tersebut, terutama pada sikap dan minat adopsi penggunanya. Oleh karena itu, hipotesis yang diambil adalah :

$\mathrm{H}_{1}$ : keunggulan relative berepengaruh positif terhadap persepsi kegunaan

$\mathrm{H}_{2}$ : keunggulan relative berepengaruh positif terhadap sikap

\subsection{Pengaruh Persepsi Kemudahan terhadap Persepsi Kegunaan dan Sikap}

Kemudahan penggunaan teknologi berkitan dengan proses mempelajari penggunaan teknologi. Semakin mudah teknologi digunakan, maka akan semakin meningkatkan nilai kegunaan dari teknologi tersebut bagi penggunanya. Menurut (Kulviwat et al., 2007) kemudahan penggunaan yang dirasakan dapat menjadi penerimaan awal sebuah inovasi teknologi dan sangat penting sebagai penentu adopsi dan penggunaan teknologi secara berkelanjutan. Dengan demikian hipotesis yang diambil adalah :

$\mathrm{H}_{3}$ : persepsi kemudahan berpengaruh positif terhadap persepsi kegunaan

$\mathrm{H}_{4}$ : persepsi kemudahan berpengaruh positif terhadap sikap

\subsection{Pengaruh Persepsi Kegunaan terhadap Sikap}

Persepsi Kegunaan (perceive usefulness) menurut (Kulviwat, et al. 2007) didefinisikan sebagai suatu tingkat kepercayaan seseorang bahwa teknologi akan menambah produktifitas dan performa kinerja pekerjaan mereka. Kemungkinan yang terjadi dengan menggunakan teknologi dapat memberikan keuntungan pemakai dan membantu menjalankan suatu tugas. Sebuah badan besar penelitian TAM telah menujukkan bahwa manfaat yang dirasakan oleh pengguna adalah penentu kuat penerimaan pengguna, adopsi, dan penggunaan perilaku. Dengan demikian hipotesis yang diambil adalah sebagai berikut:

$\mathrm{H}_{5}$ : Persepsi kegunaan berpengaruh positif terhadap sikap 


\section{Journal of Software Engineering Ampera}

Vol. 2, No. 3, Oktober 2021 e-ISSN: 2775-2488

https://journal-computing.org/index.php/journal-sea/index

\subsection{Pengaruh Kesenangan terhadap Sikap}

Pleasure atau kesenangan adalah sejauh mana seseorang mengalami reaksi menyenangkan terhadap suatu rangsangan fisik ataupun sosial (Mehrabian \& Russell, 1974). Kesenangan menggunakan teknologi memiliki efek langsung tehadap sikap dan keputusan penggunaan teknologi tersebut secara berkelanjutan. Demkian pula dengan kesenangan menggunakan Si Demang dapat memicu pemakaian Si Demang dilain waktu. Maka, hipotesis yang diambil adalah:

$\mathrm{H}_{6}$ : Kesenangan berpengaruh positif terhadap sikap

\subsection{Pengaruh Keinginan terhadap Sikap}

Dalam konteks pemasaran, keinginan atau gairah dapat mempengaruhi perilaku dan pembentukan sikap. Dalam beberapa penelitian menunjukkan hubungan positif antara pembeli yang tertarik barang di toko dan sikap mereka dalam membelanjakan di toko (Kulviwat et al., 2007). Berdasarkan hal tersebut, maka hipotesis yang diambil adalah :

$\mathrm{H}_{7}$ : Keinginan berpengaruh positif terhadap sikap

\subsection{Pengaruh Dominansi terhadap Sikap}

Perasaan yang berhubungan dengan berada di kendali adalah aspek utama dari dominansi. Menurut (Kulviwat et al., 2007) dominasi berlawanan dengan ketundukan atau takluk, takluk dapat berupa perasaan kecemasan, kebingungan dan ketakutan. Hal tersebut dapat berefek pada sikap negatif terhadap teknologi. Berdasarkan hal tersebut, hipotesis yang diambil adalah:

$\mathrm{H}_{8}$ : Dominasi berpengaruh positif terhadap sikap

\subsection{Pengaruh Sikap terhadap Minat Menggunakan Si Demang}

Sikap merupakan perasan positif atau negatif (pengaruh evaluatif) tentang melakukan sesuatu yang ingin dilakukan. Sikap yang akan timbul terhadap penggunaan teknologi informasi adalah positif atau negatif, apabila teknologi tersebut dirasakan baik maka sikap yang timbul adalah positif dan sebaliknya (Fishbein \& Ajzen, 1975). Minat (intention) adalah keinginan untuk melakukan perilaku, sedangkan perilaku (behavior) adalah tindakan nyata yang dilakukan. Minat untuk mematuhi aturan administratif kelurahan adalah kecenderungan yang mendorong seseorang pada keputusan yang mendukung tindakan administratif, begitupun sebaliknya. Oleh sebab itu hipotesis yang diambil adalah:

$\mathrm{H}_{9}$ : Sikap berpengaruh positif terhadap minat menggunakan Si Demang. 


\section{Journal of Software Engineering Ampera}

Vol. 2, No. 3, Oktober 2021 e-ISSN: 2775-2488

https://journal-computing.org/index.php/journal-sea/index

\subsection{Kerangka Pemikiran Teoritis}

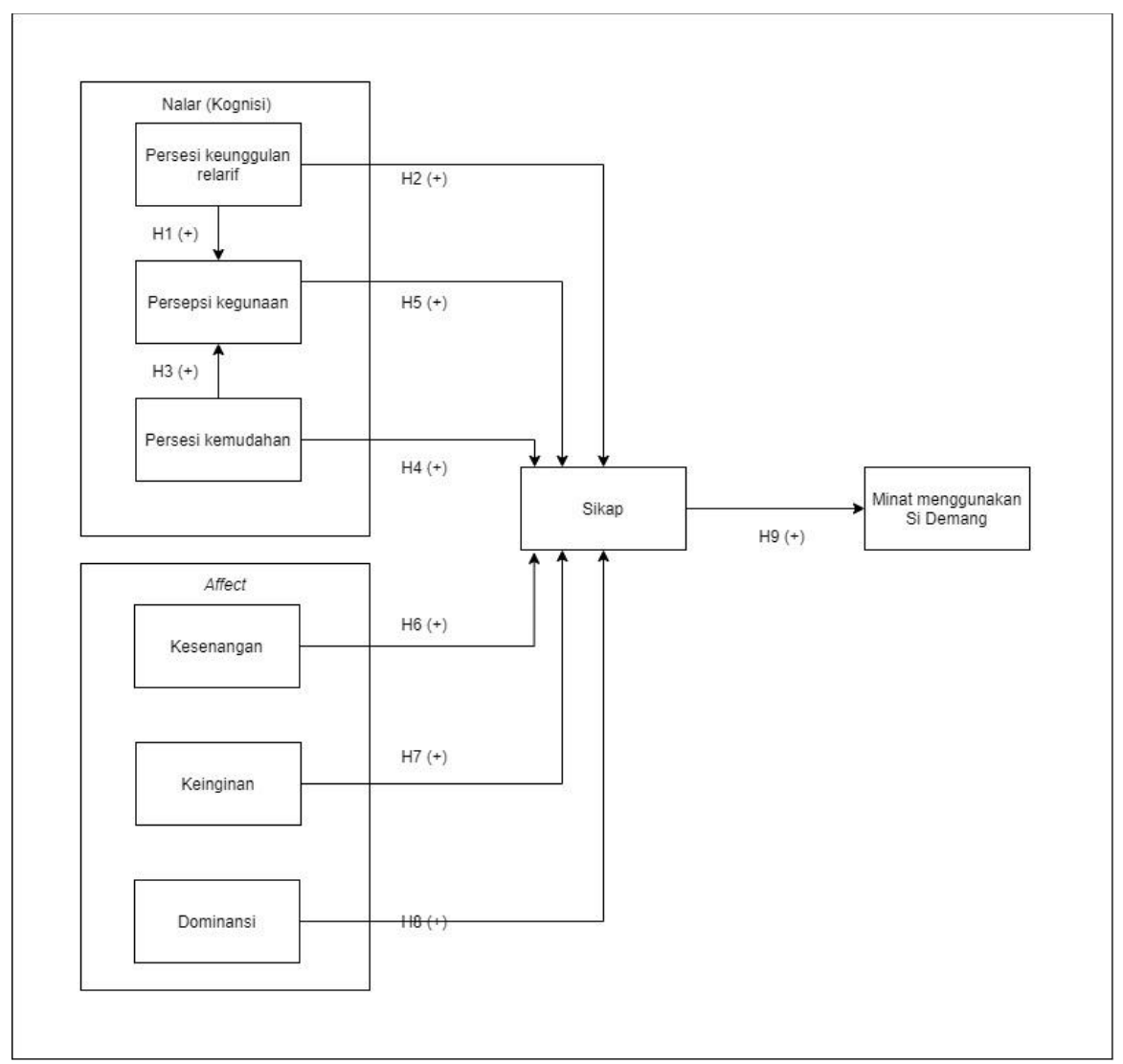

\section{METODE PENELITIAN}

\subsection{Populasi dan Teknik Pengambilan Sampel}

Dalam penelitian ini populasi yang digunakan adalah masyarakat di kelurahan kalidoni yang sudah pernah menggunakan layanan Si Demang untuk pengurusan berkas administrasi. Penentuan sampel dilakukan dengan teknik random sampling, dengan menggunakan rumus Slovin didapatkan sampel sebanyak 375 orang. Data diperoleh dengan cara menyebarkan kuisioner kepada 375 sampel responden yang berada di kelurahan kalidoni.

\subsection{Metode Analisis Data}

Berdasarkan metode yang digunakan dalam penelitian ini metode analisis menggunakan teknik structural equation modeling (SEM) dengan dua tahapan pengujian yaitu pengujian outer model atau pengujian model pengukuran, pengujian 


\section{Journal of Software Engineering Ampera}

Vol. 2, No. 3, Oktober 2021 e-ISSN: 2775-2488

https://journal-computing.org/index.php/journal-sea/index

inner model atau pengujian model structural serta pengujian hipotesis. Sebelum dilakukan pengujian, data yang didapat dari kuisioner diolah dan di rekapitulasi menggunakan software Microsoft excel, pengujian outer dan inner model menggunakan metode partial least squares (PLS) dengan software smartPLS. PLS adalah teknik statistika multivariat yang melakukan pembandingan antara variabel independent berganda dan variabel dependen jamak (Ghozali \& Latan, 2015).

\subsection{VARIABEL PENELITIAN DAN DEFINISI OPERASIONAL VARIABEL}

Keunggulan Relatif: Relative advantage atau persepsi keunggulan relative menurut (Kulviwat et al., 2007) seseorang memilih mengadopsi suatu teknologi karena memiliki keunggulan dari teknologi lain atau lebih unggul dari teknologi sebelumnya. Menurut (Rogers, 2003) keunggulan relatif berarti bahwa inovasi tersebut diyakini oleh orang yang menggunakannya memiliki keunggulan dibandingkan inovasi lain yang sejenis.

Persepsi Kegunaan: Persepsi Kegunaan (perceive usefulness) menurut (Kulviwat, et al. 2007) didefinisikan sebagai suatu tingkat kepercayaan bahwa teknologi akan menambah produktifitas dan performa kinerjanya. Dalam hal ini persepsi kegunaan dapat diartikan sebagai manfaat teknologi bagi pemakai.

Persepsi Kemudahan: Menurut (Kulviwat et al., 2007) kemudahan penggunaan adalah sejauh mana orang percaya dengan menggunakan teknologi dapat membuat pekerjaannya menjadi lebih sederhana.

Kesenangan: Kesenangan adalah perasaan atau emosi seseorang yang merupakan respon terhadap rangsangan lingkungan. Kesenangan diukur dengan penilaian reaksi lisan ke lingkungan. Kesenangan adalah dimensi afektif yang berkaitan dengan sejauh mana seseorang merasa baik, bahagia, atau puas dalam situasi tertentu (Kulviwat et al., 2007) emosi kesenangan yang negative dapat berupa kecewa, sedih, tidak puas, tidak baik.

Keinginan: Arousal menurut (A. Mehrabian \& Russell, 1974) mengacu pada tingkat dimana seseorang merasakan siaga, digairahkan, atau berada dalam situasi aktif. Gairah atau keinginan menunjukkan kombinasi aktiftas fisik dan kewaspadaan mental.

Dominansi: Dominansi berkaitan dengan control emosi atau perasaan seseorang terhadap penggunaan teknologi. Menurut (Albert Mehrabian, 1996). Dominasi diartikan sebagai perasaan berkuasa atau pengaruh situasi seseorang yang berlebihan. Sebagai salah satu dari tiga dimensi dalam model PAD, emosi bervariasi dalam jumlah dan intensitas dominasinya.

Sikap: Sikap berhubungan dengan penilaian evaluatif sesorang terhadap penggunaan teknologi. Menurut (Jogiyanto, 2007) sikap diartikan sebagai evaluasi kepercayaan berupa perasaan positif negative seseorang jika harus melakukan perilaku yang 


\section{Journal of Software Engineering Ampera}

Vol. 2, No. 3, Oktober 2021 e-ISSN: 2775-2488

https://journal-computing.org/index.php/journal-sea/index

ditentukan. Sikap mengarah pada respon dalam menangapi sesuatu diluar dirinya sendiri. Ada 3 komponen dalam sikap yaitu nalar / kognitif, pengaruh / affect, dan perilaku.

Minat Menggunakan Layanan Si Demang: Minat berperilaku menurut (Fishbein \& Ajzen, 1975) mengukur kekuatan tujuan untuk melakuka tindakan tertentu. Minat seringkali disamakan dengan perilaku, namun minat berbeda dengan perilaku. Minat adalah keinginan untuk melakukan perilaku sedangkan perilaku adalah tindakan nyata yang dilakukan. Minat terkait dengan keinginan intrinsik seseorang (keinginan dari dalam diri) untuk melakukan suatu tindakan. Minat berperilaku dalam penelitian ini adalah keinginan dalam diri untuk menggunakan teknologi layanan Si Demang.

\section{HASIL PENELITIAN DAN PEMBAHASAN}

\subsection{Pengujian Outer Model (Pengujian Model Pengukuran)}

Outer model digunakan untuk menguji validitas dan reliabilitas hubungan antara konstruk dengan indikatornya. Langkah pertama pengujian validitas dalam PLS adalah menguji validitas konvergen yan dapat dilihat dari nilai outer loading dibawah ini:

Tabel 1. Outer Loading

\begin{tabular}{cccc}
\hline Korelasi & Original Sample (O) & T-Statistic & $\begin{array}{c}\text { Persentase Korelasi } \\
\text { Konstruk dan Indikator }\end{array}$ \\
\hline RA -> RA1 & 0,783 & 3.973 & $0.05 \%$ \\
RA -> RA2 & 0,878 & 6.560 & $0.06 \%$ \\
RA -> RA3 & 0,822 & 6.168 & $0.05 \%$ \\
RA -> RA4 & 0,62 & 3.199 & $0.04 \%$ \\
PU -> PU1 & 0,871 & 7.580 & $0.05 \%$ \\
PU -> PU2 & 0,881 & 7.550 & $0.05 \%$ \\
PU -> PU3 & 0,868 & 11.502 & $0.05 \%$ \\
PU -> PU4 & 0,745 & 4.271 & $0.04 \%$ \\
PU -> PU5 & 0,53 & 2.986 & $0.03 \%$ \\
PE -> PE1 & 0,774 & 2.819 & $0.07 \%$ \\
PE -> PE2 & 0,696 & 3.095 & $0.06 \%$ \\
PE -> PE3 & 0,764 & 4.356 & $0.07 \%$ \\
PL -> PL1 & 0,878 & 3.381 & $0.05 \%$ \\
PL -> PL2 & 0,867 & 3.501 & $0.05 \%$ \\
PL -> PL3 & 0,665 & 2.604 & $0.04 \%$ \\
PL -> PL4 & 0,847 & 3.851 & $0.05 \%$
\end{tabular}




\section{Journal of Software Engineering Ampera}

Vol. 2, No. 3, Oktober 2021 e-ISSN: 2775-2488

https://journal-computing.org/index.php/journal-sea/index

\begin{tabular}{cccc} 
PL -> PL5 & 0,623 & 2.315 & $0.03 \%$ \\
AR -> AR1 & 0,807 & 2.403 & $0.07 \%$ \\
AR -> AR2 & 0,516 & 1.305 & $0.05 \%$ \\
AR -> AR3 & 0,883 & 2.644 & $0.08 \%$ \\
DO -> DO1 & 0,737 & 2.515 & $0.05 \%$ \\
DO -> DO2 & 0,861 & 2.756 & $0.06 \%$ \\
DO -> DO3 & 0,689 & 2.080 & $0.05 \%$ \\
DO -> DO4 & 0,909 & 2.670 & $0.06 \%$ \\
ATA -> ATA1 & 0,729 & 3.266 & $0.06 \%$ \\
ATA -> ATA2 & 0,887 & 6.836 & $0.08 \%$ \\
ATA -> ATA3 & 0,844 & 5.413 & $0.08 \%$ \\
AI -> Al1 & 0,731 & 2.213 & $0.06 \%$ \\
AI -> Al2 & 0,846 & 2.557 & $0.08 \%$ \\
Al -> Al3 & 0,766 & 2.098 & $0.07 \%$ \\
\hline
\end{tabular}

Dilihat nilai outer loading atau korelasi antara konstruk dan indikatornya diatas 0.50 maka dapat disimpulkan bahwa konstruk tersebut memiliki validitas konvergen yang baik. Setelah menguji validitas konvergen selanjutnya pengujian validitas diskriminan dengan melihat nilai cross loading sebagai berikut :

Tabel 2. Cross Loading

\begin{tabular}{lllllllll}
\hline & Al & AR & ATA & DO & PE & \multicolumn{1}{l}{ PU } & \multicolumn{1}{l}{ PL } & \multicolumn{1}{l}{ RA } \\
\hline Al1 & 0.731 & 0.252 & 0.161 & 0.240 & 0.057 & 0.257 & 0.161 & 0.101 \\
Al2 & 0.846 & 0.035 & 0.206 & 0.098 & 0.058 & -0.027 & 0.086 & 0.052 \\
Al3 & 0.766 & 0.240 & 0.194 & 0.420 & 0.082 & 0.006 & 0.227 & 0.061 \\
AR1 & 0.268 & 0.807 & 0.294 & 0.063 & 0.310 & 0.365 & 0.364 & 0.237 \\
AR2 & 0.052 & 0.516 & 0.089 & 0.499 & 0.290 & 0.175 & 0.275 & 0.029 \\
AR3 & 0.123 & 0.883 & 0.350 & 0.168 & 0.514 & 0.559 & 0.414 & 0.198 \\
ATA1 & 0.234 & 0.285 & 0.729 & 0.074 & 0.182 & 0.157 & 0.403 & 0.039 \\
ATA2 & 0.248 & 0.225 & 0.887 & 0.327 & 0.085 & -0.140 & 0.256 & -0.051 \\
ATA3 & 0.128 & 0.378 & 0.884 & 0.152 & 0.286 & 0.236 & 0.575 & 0.054 \\
D01 & 0.199 & 0.111 & 0.093 & 0.737 & 0.323 & 0.121 & 0.013 & -0.083 \\
D02 & 0.267 & 0.262 & 0.151 & 0.861 & 0.363 & 0.342 & -0.031 & 0.179 \\
D03 & 0.108 & 0.123 & 0.001 & 0.689 & 0.342 & 0.291 & 0.042 & 0.079 \\
D04 & 0.307 & 0.151 & 0.254 & 0.909 & 0.178 & -0.047 & 0.050 & -0.052 \\
PE1 & 0.114 & 0.352 & 0.315 & 0.256 & 0.774 & 0.467 & 0.197 & 0.286
\end{tabular}




\section{Journal of Software Engineering Ampera}

Vol. 2, No. 3, Oktober 2021 e-ISSN: 2775-2488

https://journal-computing.org/index.php/journal-sea/index

\begin{tabular}{lcccccccc}
\hline & & & & & & & & \\
PE2 & 0.087 & 0.290 & 0.089 & 0.142 & 0.696 & 0.547 & 0.234 & 0.325 \\
PE3 & -0.022 & 0.489 & 0.109 & 0.284 & 0.764 & 0.482 & 0.115 & 0.101 \\
PL1 & 0.269 & 0.446 & 0.353 & 0.036 & 0.237 & 0.212 & 0.878 & 0.204 \\
PL2 & 0.229 & 0.441 & 0.457 & -0.090 & 0.069 & 0.222 & 0.867 & 0.196 \\
PL3 & 0.335 & 0.315 & 0.333 & 0.090 & 0.325 & 0.069 & 0.665 & -0.061 \\
PL4 & 0.010 & 0.374 & 0.516 & 0.081 & 0.267 & 0.347 & 0.847 & 0.130 \\
PL5 & 0.085 & 0.218 & 0.288 & -0.035 & 0.072 & 0.140 & 0.623 & 0.038 \\
PU1 & 0.184 & 0.603 & 0.229 & 0.021 & 0.590 & 0.871 & 0.360 & 0.447 \\
PU2 & 0.137 & 0.479 & 0.127 & 0.098 & 0.582 & 0.881 & 0.258 & 0.544 \\
PU3 & 0.023 & 0.459 & 0.013 & 0.279 & 0.552 & 0.868 & 0.065 & 0.436 \\
PU4 & -0.038 & 0.267 & 0.034 & 0.050 & 0.582 & 0.745 & 0.201 & 0.443 \\
PU5 & -0.082 & 0.260 & -0.052 & -0.051 & 0.194 & 0.530 & 0.183 & 0.123 \\
RA1 & 0.072 & 0.200 & -0.126 & -0.131 & 0.176 & 0.430 & 0.134 & 0.783 \\
RA2 & 0.148 & 0.233 & 0.006 & 0.066 & 0.309 & 0.481 & 0.093 & 0.878 \\
RA3 & 0.133 & -0.028 & -0.059 & 0.064 & 0.112 & 0.301 & -0.064 & 0.822 \\
RA4 & 0.001 & 0.264 & 0.215 & 0.054 & 0.359 & 0.427 & 0.225 & 0.620 \\
\hline
\end{tabular}

Dikatakan memiliki validitas diskriminan yang baik apabila nilai korelasi indicator pada konstruknya lebih tinggi daripada konstruk yang lain. Dari tabel diatas angka tebal menunjukkan korelasi antara konstruk dan indikatornya lebih tinggi dibandingkan dengan korelasi konstruk lainnya. Hal tersebut menunjukkan bahwa adanya validitas diskriminan yang baik.

Setelah menguji validitas diskriminan selanjutnya menguji reliabilitas konstruk. Dalam PLS pengujian reliabilitas salah satunya dilakukan dengan melihat nilai composite reliability. Besarnya reliabilitas dapat dilihat dari nilai Composite reliability ataupun Cronbach alpha. Suatu konstruk dinyatakan reliable apabila nilai Composite reliability > 0.7 (Ghozali, 2018) (Abdillah, 2018).

Tabel 3. Composite Reliability

\begin{tabular}{lc}
\hline & Composite Reliability \\
\hline RA & 0.861 \\
PU & 0.890 \\
PE & 0.789 \\
PL & 0.886 \\
AR & 0.789 \\
DO & 0.879
\end{tabular}




\section{Journal of Software Engineering Ampera}

Vol. 2, No. 3, Oktober 2021 e-ISSN: 2775-2488

https://journal-computing.org/index.php/journal-sea/index

\begin{tabular}{ll} 
ATA & 0.862 \\
Al & 0.825 \\
\hline
\end{tabular}

Dari tabel diatas dan berdasarkan rule of thumb yang ada maka dapat disimpulkan bahwa konstruk memiliki reliabilitas yang baik sehingga item pertanyaan yang menyusun variabel penelitian mempunyai internal konsistensi yang tinggi dan dapat digunakan dalam penelitian.

\subsection{Pengujian Inner Model (Pengujian Model Struktural)}

Inner model merupakan model structural untuk memprediksi hubungan kausalitas antar variabel laten melalui proses bootstrapping (Abdillah, 2018). Model structural dalam PLS dievaluasi dengan menggunakan $R^{2}$ untuk konstruk dependen, nilai koefisien path atau $t$-values tiap path untuk menguji signifikasi antar konstruk dalam model structural.

Tabel 4. $R$ Square

\begin{tabular}{|c|c|c|}
\hline Konstruk & R Square & Makna Goodness Fit Model \\
\hline Adoption Intention (Al) & 0.058 & $\begin{array}{l}\text { Lemah dan } 5.8 \% \text { variabilitas Adoption Intention atau } \\
\text { minat (Al) dapat dijelaskan oleh variabilitas Attitude } \\
\text { atau sikap (ATA) dan sisanya } 94.2 \% \text { dipengaruhi oleh } \\
\text { variabel lain. }\end{array}$ \\
\hline Arousal (AR) & & Tidak dapat dijelaskan \\
\hline Dominance (DO) & & Tidak dapat dijelaskan \\
\hline Pleasure (PL) & & Tidak dapat dijelaskan \\
\hline Perceive Usefulness (PU) & 0.568 & $\begin{array}{l}\text { Moderate dan } 56.8 \% \text { variabilitas Perceive Usefulness } \\
\text { (PU) } \\
\text { dapat dijelaskan oleh variabilitas Perceive Ease of Use } \\
\text { (PE) dan Relative Advantage (RA). Sisanya sebesar } \\
\text { 43.2\% dipengaruhi oleh variabilitas lain. }\end{array}$ \\
\hline Attitude (ATA) & 0.338 & $\begin{array}{l}\text { Lemah dan 33.8\% variabilitas Attitude (ATA) dapat } \\
\text { dijelaskan oleh variabilitas Relative Advantage (RA), } \\
\text { Perceive Usefulness (PU), Perceive Ease Of Use (PE), } \\
\text { Pleasure (PL), Arousal (AR) dan Dominance (DO). Sisa } \\
\text { nya sebesar 66.2\% dipengaruhi oleh variabel lain. }\end{array}$ \\
\hline Relative Advantage (RA) & & Tidak dapat dijelaskan \\
\hline
\end{tabular}

\subsection{Pengujian Hipotesis}

Pengujian hipotesis dengan sempls menggunakan software Smartpls dilakukan melalui proses bootstrapping dengan melihat nilai Original Sample (O) dan T - Statistic pada table path coefficient. Kriteria pengujian $(\alpha)=0.05$ ditentukan sebagai berikut : 


\section{Journal of Software Engineering Ampera}

Vol. 2, No. 3, Oktober 2021 e-ISSN: 2775-2488

https://journal-computing.org/index.php/journal-sea/index

1. Apabila t hitung $>\mathrm{t}$ tabel maka $\mathrm{H}_{0}$ ditolak dan Ha diterima

2. Apabila $\mathrm{t}$ hitung $<\mathrm{t}$ tabel maka $\mathrm{H}_{0}$ diterima dan Ha ditolak

Tabel 5. Path Coefficient

\begin{tabular}{|c|c|c|c|c|c|}
\hline & $\begin{array}{c}\text { Original } \\
\text { Sample (O) }\end{array}$ & $\begin{array}{c}\text { Sample } \\
\text { Mean (M) }\end{array}$ & $\begin{array}{c}\text { Standard } \\
\text { Deviation } \\
\text { (STDEV) }\end{array}$ & $\begin{array}{c}\text { T Statistics } \\
(|\mathrm{O} / \mathrm{STDEV}|)\end{array}$ & $\begin{array}{c}\mathrm{P} \\
\text { Valu } \\
\text { es }\end{array}$ \\
\hline RA -> & & & & & 0.00 \\
\hline PU & 0.401 & 0.402 & 0.046 & 8.711 & 0 \\
\hline $\mathrm{RA}->$ & & & & & 0.94 \\
\hline ATA & -0.004 & -0.005 & 0.056 & 0.070 & 4 \\
\hline PE -> & & & & & 0.00 \\
\hline PU & 0.254 & 0.255 & 0.046 & 5.550 & 0 \\
\hline$P E->$ & & & & & 0.39 \\
\hline ATA & 0.043 & 0.041 & 0.051 & 0.850 & 6 \\
\hline PU $\rightarrow$ & & & & & 0.00 \\
\hline ATA & 0.179 & 0.178 & 0.056 & 3.176 & 2 \\
\hline PL -> & & & & & 0.00 \\
\hline ATA & 0.162 & 0.164 & 0.053 & 3.061 & 2 \\
\hline$A R \rightarrow$ & & & & & 0.04 \\
\hline ATA & 0.101 & 0.105 & 0.050 & 2.014 & 5 \\
\hline DO -> & & & & & 0.00 \\
\hline ATA & 0.258 & 0.261 & 0.050 & 5.140 & 0 \\
\hline ATA $\rightarrow$ & & & & & 0.00 \\
\hline $\mathrm{Al}$ & 0.424 & 0.429 & 0.046 & 9.275 & 0 \\
\hline
\end{tabular}

Berdasarkan tabel path coefficients dengan melihat original sample dan T statistik nya dapat disimpulkan bahwa hipotesis 1, 3, 5, 6, 7, 8, 9 bernilai positif dan signifikan karena memiliki nilai original sampel positif dan Tstatistik yang lebih tinggi daripada 1,96. Sedangkan hipotesis 2 dan 4 bernilai tidak signifikan dan ditolak karena nilai Tstatistik kurang dari 1,96.

\section{KESIMPULAN DAN SARAN}

Berdasarkan masalah yang ada dalam peneltian dan pembahasan pada bab sebelumnya, maka penelitian ini dapat ditarik kesimpulan sebagai berikut:

1. Persepsi keunggulan relative (RA) berpengaruh positif terhadap persepsi kegunaan (PU). Hal ini menunjukkan bahwa semakin tinggi keunggulan relative pada aplikasi Si Demang maka akan semakin tinggi pula persepsi kegunaan dari aplikasi Si Demang. Berdasarkan hal ini maka hipotesis yang menyatakan persepsi keunggulan relative berpengaruh terhadap persepsi kegunaan dapat diterima karena signifikan. 


\section{Journal of Software Engineering Ampera}

Vol. 2, No. 3, Oktober 2021 e-ISSN: 2775-2488

https://journal-computing.org/index.php/journal-sea/index

2. Persepsi keunggulan relative (RA) tidak berpengaruh positif terhadap sikap pengguna Si Demang (ATA). Hal ini menunjukkan semakin tinggi persepsi keunggulan relative pada aplikasi Si Demang tidak akan mempengaruhi sikap terhadap Si Demang. Berdasarkan hal ini maka hipotesis yang menyatakan keunggulan relative berpengaruh positif terhadap sikap dapat ditolak karena tidak signifikan.

3. Persepsi kemudahan (PE) berpengaruh positif terhadap persepsi kegunaan (PU). Hal ini menunjukkan bahwa semakin tinggi persepsi kemudahan atas $\mathrm{Si}$ Demang maka persepsi kegunaan juga akan meningkat. Berdasarkan hal ini hipotesis yang menyatakan persepsi kemudahan berpengaruh positif terhadap persepsi kegunaan dapat diterima karena signifikan.

4. Persepsi kemudahan (PE) tidak berpengaruh positif terhadap sikap (ATA). Hal ini menunjukkan bahwa semakin tinggi persepsi kegunaan atas Si Demang tidak mempengaruhi sikap untuk menggunakan Si Demang. Berdasalkan hal tersebut maka hipotesis yang menyatakan persepsi kemudahan berpengaruh poositif terhadap sikap dapat ditolak karena tidak signifikan.

5. Persepsi kegunaan (PU) berpengaruh positif terhadap sikap (ATA). Hal ini menunjukkan bahwa semakin tinggi persepsi kegunaan atas Si Demang maka akan semakin tinggi pula sikap untuk menggunakan Si Demang. Berdasarkan hal tersebut hipotesis yang menyatakan persepsi kegunaan berpengaruh positif terhadap sikap dapat diterima karena signifikan.

6. Kesenangan (PL) berpengaruh positif terhadap sikap (ATA). Hal ini menjunjukkan semakin tinggi kesenangan pada saat menggunakan Si Demang maka akan semakin tinggi pula sikap untuk menggunakan Si Demang. Berdasarkan hal tersebut maka hipotesis yang menyatakan kesenangan berpengaruh positif terhadap sikap dapat diterima karena signifikan.

7. Keinginan (AR) berpengaruh positif terhadap sikap (ATA). Hal ini menunjukkan bahwa semakin tinggi keinginan menggunakan Si Demang maka akan semakin tinggi pula sikapnya untuk menggunakan Si Demang. Berdasalkan hal tersebut maka hipotesis yang menyatakan keinginan berpengaruh positif terhadap sikap dapat diterima karena signifikan.

8. Dominasi berpengaruh positif terhadap sikap. Hal ini menunjukkan bahwa semakin tinggi dominasi penggunaan Si Demang maka akan semakin tinggi pula sikap seseorang untuk menggunakan Si Demang untuk pengurusan administrasi. Dengan hal tersebut hipotesisi yang menyatakan dominasi berpengaruh positif terhadap sikap dapat diterima karena signifikan.

9. Sikap (ATA) berpengaruh positif terhadap minat menggunakan Si Demang. Hal ini menunjukkan bahwa semakin baik sikap untuk menggunakan Si Demang maka semakin tinggi minat nya untuk menggunakan Si Demang.

Berdasarkan kesimpulan dari penelitian ini maka saran yang dapat diajukan dari peneliti untuk Dinas Komunikasi dan Infomatika Kota Palembang agar dapat meningkatkan penggunaan layanan sistem informasi administrasi Si Demang dengan meningkatkan persepsi kegunaan, kesenangan, keinginan, dan. Selain itu untuk meningkatkan 


\section{Journal of Software Engineering Ampera}

Vol. 2, No. 3, Oktober 2021 e-ISSN: 2775-2488

https://journal-computing.org/index.php/journal-sea/index

kemudahan layanan Si Demang bagi masyarakat di kelurahan Kalidoni, perlu dimaksimalkan tata cara atau petunjuk pengisian secara lebih lengkap dan mudah dipahami agar masyarakat pun merasa tidak kesulitan dalam mengoperasikan layanan Si Demang. Serta menyediakan lebih banyak fitur yang dibutuhkan masyarakat. Selain itu perlunya meningkatkan sosialisasi tentang layanan Si Demang kepada masyarakat di kelurahan kalidoni karena masih banyak masyarakat di kelurahan kalidoni bahkan tidak tahu adanya layanan ini.

\section{REFERENSI}

Abdillah, W. (2018). Metode Penelitian Terpadu Sistem Informasi, Pemodelan Teoretis, Pengukuran, dan Pengujian Statis. In Metode Penelitian Terpadu Sistem Informasi, Pemodelan Teoretis, Pengukuran, dan Pengujian Statis.

Al Fatta, H. (2007). Analisis dan Perancangan Sistem Informasi untuk Keunggulan Bersaing Perusahaan dan Organisasi Modern. In Andi Offset. https://doi.org/10.1017/CBO9781107415324.004

Areni, C., Sparks, J., \& Dunne, P. (1996). Assessing Consumers; Affective Responses to Retail Environments: A Tale of Two Simulation Techniques. Advances in Consumer Research.

Augusty, F. (2012). Metode Penelitian Manajemen, Pedoman Penelitian Untuk Skripsi. Tesis Dan Desertasi Ilmu Manajemen. Semarang: Universitas Diponegoro. Journal of Manajemen.

Bakker, I., van der Voordt, T., Vink, P., \& de Boon, J. (2014). Pleasure, Arousal, Dominance: Mehrabian and Russell revisited. Current Psychology. https://doi.org/10.1007/s12144-014-9219-4

Barata, A. A. (2003). Dasar-dasar pelayanan prima. In PT. Elex Media Komputindo.

Chinn, W. W. (1998). The Partial Least Squares Approach to Structural Equation Modelling. Modern Methods for Business Research.

Davis, F. D. (1985). A technology acceptance model for empirically testing new enduser information systems: Theory and results. Management. https://doi.org/oclc/56932490

Fishbein, M., \& Ajzen, I. (1975). An Introduction to Theory and Research. In Belief, Attitude, Intention, and Behavior, An Introduction to Theory and Research. https://doi.org/10.2307/2065853

Ghozali, I. (2018). Aplikasi Analisis Multivariate dengan Program IBM SPSS. Yogyakarta: Universitas Diponegoro. (Edisi 9). Semarang: Badan Penerbit Universitas Diponegoro.

Ghozali, I., \& Latan, H. (2015a). Konsep, Teknik Dan Aplikasi Menggunakan Program Smart PLS 3.0. In Universitas Diponegoro. Semarang.

Ghozali, I., \& Latan, H. (2015b). Partial Least Squares: Konsep, Teknik dan Aplikasi Smart PLS 3.0 untuk Penelitian Empiris. In Universitas Diponegoro.

Koufaris, M. (2002b). Koufaris, M., 2002. Applying the technology acceptance model and flow theory to online consumer behavior. Information Systems Research 13 


\section{Journal of Software Engineering Ampera}

Vol. 2, No. 3, Oktober 2021 e-ISSN: 2775-2488

https://journal-computing.org/index.php/journal-sea/index

(2), 205-223. Applying the Technology Acceptance Model and Flow Theory to Online Consumer Behavior.

Kulviwat, S., Bruner, G. C., Kumar, A., Nasco, S. A., \& Clark, T. (2007). Toward a unified theory of consumer acceptance technology. Psychology and Marketing. https://doi.org/10.1002/mar.20196

Mehrabian, A., \& Russell, J. A. (1974). The basic emotional impact of environments. Perceptual and Motor Skills. https://doi.org/10.2466/pms.1974.38.1.283 